\title{
Now: A Post-Romantic Countertextuality of the Contemporary'
}

\author{
James Corby \\ (University of Malta)
}

\begin{abstract}
:
In this essay James Corby questions the dominant future-oriented nature of the ethical turn of theory and philosophy in the final decades of the twentieth century and its aesthetic influence. Focusing in particular upon the ethical position of Jacques Derrida, Corby argues that the desire to avoid the closure of the contemporary and to preserve the possibility of difference by cultivating a radical attentiveness to that which is 'to come' often risks a too complete disengagement from the present, leading to an empty and ineffectual ethical stance that actually preserves the contemporary situation that it seeks to open up. Corby makes a case for this theoretical investment in the possibility of a non-contemporary (typically futural) rupture as being understood as forming part of a far-reaching romantic tradition. In opposition to this tradition he sketches a post-romantic alternative that would understand difference as an immanent, rather than imminent, matter. He argues that this should be considered congruent with a countertextual impulse oriented not towards a revelatory futurity, but, rather, towards the possible displacements, dislocations, and transformations already inherent in the contemporary. The final part of the essay develops this idea, positioning countertextuality as the articulation of alternative contemporaries. In this regard, the literature of the future is not 'to come', it is already here. The challenge is to recognise it as such, and this means being prepared to modify and change the conceptual apparatus that guides us in our thinking of literature and the arts.
\end{abstract}

Keywords: future, theory, ethics, politics, Derrida, romanticism, post-romanticism, countertextuality.

The countertextual, as it is being envisaged by the editors of CounterText, is that quality in any manifestation of the literary that performatively calls literature to account, implicitly raising the question of how it might be otherwise than it is now and has been in the past. Perhaps inevitably, then, the countertextual will be seen as 'oriented

CounterText 1.2 (2015): 186-206

DOI: $10.3366 /$ count.2015.0017

(C) Edinburgh University Press

www.euppublishing.com/journal/count 
to the future', as was stated in the Editorial of the first issue of CounterText (Callus and Corby 2015: v). It would be entirely mistaken, however, to elide that orientation to the future into speculation about how literature in the future might be otherwise than it is now. The temptation to do so is understandable, and in the paradigm of late capitalist futurophilia it would fit in with the ubiquitous contemporary cultural tendency towards excitable futurology. However, futurophilia often occupies the other end of the spectrum, treating the future as a radically vacant and unknowable space, rather than trying to furnish it with content. In this scenario, invocation of the future is treated as a provocation to thought, seeming to introduce into our calculations the element of the indeterminate and incalculable, giving the impression that we are, in an eminently critical way, bracketing the present state of things in order to reconsider everything by the lights of an unscripted future. The future, in other words, is often invoked as offering a blank category that necessitates a suspension of what is thought to be known, either in order to fantasise about what the future might be like, or as a mechanism to suspend the apparent certainties of the present and thereby clear a space for thinking. Both futurophilial tendencies can be co-opted as seemingly salutary procedures for puncturing complacency and moving history forwards. When applied to the question of literature, 'the future' seems to respond to the belief that the only appropriate responses to the question of literature will be those that issue from unconstrained - what marketing people call 'blue skies' - thinking.

This, I suggest, is an illusion, and a dangerous one at that, and ought to be strongly resisted. While seeming to establish the scene of unconditioned thinking, invocation of the future in fact risks militating in precisely the opposite direction. Thinking prompted by a futurological imperative resists thought by bracketing the contemporary conditions of thinking, foreclosing the potential for true innovation, ensuring that thought remains fastened to unexamined contemporary presuppositions and forms. Not only does the invocation of the future in this context impose blinkers on thought, it does so while at the same time giving the impression that it is in fact this very manoeuvre that watches over thinking, guarding it against limitations. The bracketing of the present state of things (what, in shorthand, we call the contemporary) in order to clear the ground for the future, where the future represents a principle of difference, is liable, in effect, to preserve the present state of things. One might think of this as a sort of aufhebung of the contemporary, whereby the contemporary is simultaneously cancelled, elevated, and preserved. Jacques Rancière argues that our sense of the contemporary regulates the relationship between what we consider the possible and the impossible (2012: 12-14), and a futurological orientation risks simultaneously fixing that regulation in place while removing it from the possibility of interrogation. This means that although future-thinking calls on us to think of the future as different from the present, the options, or, more accurately, the range of difference available for our consideration, remain prescribed or-perhaps a little less strongly, but with the same effect-conditioned by the present. It is in this way that futurophilia tends to fix in place the blinkers it purports to remove. 
In this paper I will argue that in thinking the countertextual and the post-literary, rather than suspending or bracketing the contemporary for the sake of the future and of the literary to come, we perhaps ought to suspend the future for the sake of the contemporary and the literary today. The task of interrogating and reconfiguring the contemporary is not simply more pressing than speculating about the future, it might actually be considered the real work of the future today, since without it there can be no future worthy of the name. Without a critical interrogation of the contemporary, we are-barring deliverance by an unforeseen catastrophe-condemned simply to an ongoing reiteration of the present.

In 'Force of Law: The "Mystical Foundation of Authority"', Jacques Derrida remarks in the context of a discussion of law and justice:

[Justice] has no horizon of expectation (regulative or messianic). But for this very reason, it may have an avenir, a 'to-come', which I rigorously distinguish from the future that can always reproduce the present. (Derrida 1990: 969)

This quotation, representative both of the Levinas-inspired ethics operative in Derrida's middle and late writings, and of the broader poststructuralist ethical turn in theory of which it formed an important part, is indicative of how the very theoretical positions that purport to endorse a principle of radical heterogeneity can in fact risk complicity in facilitating and preserving the sameness of the present. In such instances attention is diverted from the contemporary to the future on the basis of an ethical imperative. The idea, of course, is that by being vigilant for that which is not yet, and by maintaining the possibility of a radically open future that is always 'to come', one accedes to an empty and asymptotic horizon of anticipation that resists the inimical closure of the present.

If the word 'law' can be understood as naming everything that stands for this closure, then 'justice', in a sort of secular Judaic messianicity, comes to stand for the radical opening that would resist that closure. The ethical experience would be the willingness to bracket law for the sake of a principle of heterogeneity attested to by the opening of the future, on the basis of which the space of the political is opened. It is in this way that deconstruction is identified with ethics and justice and is thereby established firmly on the side of the future. Of course, there is a more prosaic sense in which deconstruction, through its investments in 'writing', broadly and variously understood, will always, inevitably, be drawn to the future. As Geoffrey Bennington observes in the essay 'Towards a Criticism of the Future', 'there is an obviousness about the link of writing to the future (one writes when the absence of the addressee makes speaking impracticable, but in view of a future presence of that addressee)' (1994: 230). But what is of more profound interest for Derrida is the constant possibility that such writing does not meet - in the intended way, or perhaps even at all - an adequate addressee. The possibility, that is to say, of the dead letter, the letter that does not arrive at its intended destination. It is in the always possible failure of writing to be received properly - or, to put it even more strongly, in the impossibility of writing to be 
only received properly - that a monstrous, futural alterity may announce itself (see, for instance, Derrida 1976: 5). In Derrida and the Future of Literature, Joseph Kronick (whose name, at least homophonically, is bizarrely appropriate given that 'chronic' means lasting a long time, and is derived from the Latin chronicus, meaning 'of, or concerning time') writes:

Deconstruction shares with literature this status as an event marked not by an internal criterion but by its movement toward the other. Deconstruction and literature - and by 'literature' I mean a particular kind of writing that does not necessarily coincide with belles lettres or the institution of 'Literature' - produce monstrosities, a writing that grafts itself onto traditions (for a monster is, by definition, a kind of hybrid violating a norm) and beckons toward something other. (103)

Kronick also comments that 'Derrida's passion for literature must be seen as a passion for something to come, an impossible something, which he frequently calls "justice" or "democracy" [... ] Derrida's "literature" must be thought of as a quasi-transcendental condition for the coming of the other' (3). Literature, then, he concludes, is for Derrida 'invariably linked to ethics' (3). Certainly, in 'Force of Law' Derrida identifies deconstruction with justice (1990: 945), and justice, he suggests, 'remains, is yet, to come, à venir', which he is at pains to distinguish from 'the future that can always reproduce the present' (969). In On the Name Derrida argues that literature is capable, in principle, of saying everything, which aligns it with the possibility of democracy: 'No democracy without literature; no literature without democracy' (1995: 28).

Why, then, despite such claims to the contrary, might it be suggested that this sort of radicalisation of the future on ethical and political grounds is complicit in supporting the homogeneity that it purports to resist? Prima facie it seems difficult to maintain that the futurophiliac tendencies in Derrida's thinking involve a forgetting of the contemporary. Not only is futurity important precisely on account of the present, but the future must be invoked in some sort of disruptive collocation with the present. As he says in Spectres of Marx, 'No differance without alterity, no alterity without singularity, no singularity without here-now' (1994: 31). The future haunts the present as an unrecognised alterity that is immanent within the coercive unity of the contemporary. The future as a principle of heterogeneity is, therefore, temporally imminent (yet, never-to-come) insofar as it is already (or 'always already', in the theoretical patois) spatially immanent within the otherwise timeless contemporary. This is what Nietzsche called the 'untimely', and I will return to that, and perhaps not before time. There is a structural homology with the idea of the pharmakon, the notion that the poison can also act as the cure (Derrida 1993b), similia similibus curentur. Here, however, there is not a complete identity of poison and cure, but instead a critical and necessary proximity between the two, an idea that Derrida inherits from Heidegger (1977: 28), and which Heidegger takes from Hölderlin, whose 'Patmos' proclaims: 'Wo aber Gefahr ist, wächst / Das Rettende auch' (But where danger threatens / That which saves from it also grows') (Hölderlin 2004: 550, 551). This, 


\section{CounterText}

broadly speaking, is adapted to become the logic of spectrality that Derrida unfolds in Spectres of Marx. He writes: 'It is necessary to speak of the ghost, indeed to the ghost and with it, from the moment that no ethics, no politics, whether revolutionary or not, seems possible and thinkable and just that does not recognise in its principle the respect for those others who are no longer or for those others who are not yet there, presently living, whether they are already dead or not yet born' (1994: xix). This is what he calls 'the principle of some responsibility, beyond all living present, within that which disjoins the living present', or, more succinctly, the 'non-contemporaneity with itself of the living present' (xix), which Bennington, in an essay called 'Is it Time?', refers to as 'a condition of possibility of responsibility and justice' (2001: 23). That which haunts the contemporary, and 'secretly unhinges it' (Derrida 1994: xix), is not simply the spectral return of the past (though it is that too). What, for Derrida, haunts the contemporary, and subsumes the past, is the future, functioning as an ethical imperative insofar as it maintains a radical opening that safeguards the principle of heterogeneity.

This spectral haunting of the present by the future prompts, self-reflexively, questions about itself: “"where?” "where tomorrow?” "whither?” (Derrida 1994: xix). The future, in other words, announces itself as its own question, which may recall Blanchot's figuring of romanticism as the historical moment when literature ceases to be a response and becomes a question (Blanchot 2003: 358), thereby founding the future (356). Derrida goes on:

This question arrives, if it arrives, it questions with regard to what will come in the futureto-come. Turned toward the future, going toward it, it also comes from it, it proceeds from the future. It must therefore exceed any presence to itself. At least it has to make this presence possible only on the basis of the movement of some disjointing, disjunction, or disproportion: in the inadequation to self. (1994: xix)

This question, which Derrida explicitly states can be called 'justice' (1994: xx), 'can clearly come only from the future' (xix). It must 'carry beyond present life . . beyond therefore the living present in general' (xx):

beyond the living present in general - and beyond its simple negative reversal. A spectral moment, a moment that no longer belongs to time, if one understands by this word the linking of modalised presents (past present, actual present: 'now', future present). We are questioning in this instant, we are asking ourselves about this instant that is not docile to time, at least to what we call time. $(\mathrm{xx})$

The implication is clear: it is because the contemporary matters that it must be put aside, bracketed for the sake of the possibility of a better - more just - contemporaryto-come, and the condition of the possibility of this more just contemporary-tocome, the trigger that suspends the present, is the future that will never come, never be present, and our ongoing, tireless vigilance with regard to that future. 
An ethical education would involve learning to live 'finally', learning to live, that is to say, in 'a time without tutelary present' (Derrida 1994: xviii). My concern is that the severity of the ethical imperative of Derrida's futurophilia necessitates a too complete disengagement with the present. This encourages a tendency to understand a correction to the contemporary as taking place primarily along a temporal plane, unfolding according to a certain temporal sequencing (even if, as is the case, that temporal sequencing is anachronous with regard to the unifying narrative strategies of historiographical time - 'homogeneous, empty time', as Walter Benjamin puts it [2006: 385] - and is properly responsive to all of the complexities and paradoxes of the 'post-' [see, for instance, Lyotard 1993]). This, in effect, inverts what I have suggested is the true logic of spectrality, namely that the temporal imminence of the future must be correlated to a 'prior' heterogeneity that is spatially immanent within the contemporary. The latter position would acknowledge more prominently the fact that the 'present' is decided, primarily and for the most part, by ways in which the contemporary situation is mapped out or distributed. Change will inevitably take place along a temporal plane, but the potential for radical change is already established on the principle of spatial distribution. On the basis of his reading of Plato and Aristotle, Rancière understands this sort of change as politics itself:

Politics occurs when those who 'have no' time take the time necessary to front up as inhabitants of a common space and demonstrate that their mouths really do emit speech capable of making pronouncements on the common which cannot be reduced to voices signalling pain. This distribution and redistribution of places and identities, this apportioning and reapportioning of spaces and times, of the visible and the invisible, and of noise and speech constitutes what I call the distribution of the sensible. Politics consists in reconfiguring the distribution of the sensible which defines the common of a community, to introduce into it new subjects and objects, to render visible what had not been, and to make heard as speakers those who had been perceived as mere noisy animals. (Rancière 2009: 24-5)

It would, then, finally, be a mistake to understand the contemporary as having to be succeeded by another contemporary through a movement of time. Rather, the contemporary is, in Paul Rabinow's words, 'a moving ratio of modernity' (2008: 2), and, as such, the possibility of another, different, contemporary is already present; that is to say it is contemporary, not futural, and thus we ought to seek it in the contemporary, not in the future. Rather than a succession of increasingly more just contemporary moments, we ought perhaps to think, first and foremost, of a more just spatial redistribution - a potential contemporary that is already present, countertextually, we might say, in the contemporary hegemony. Thus whereas the more promising way of understanding the ethical transformation of the contemporary would involve dislocating the contemporary from the position of the contemporary, Derrida seems to advocate dislocating the contemporary by means of a temporal shift from the 
position of the future. The spectral is, finally, primarily imminent, not immanent, in Derrida's ethical thinking.

To pre-empt one obvious objection - and to clarify - this is not to suggest that these two possibilities are stark, mutually exclusive opposites. Transformation of the contemporary is necessarily both spatial and temporal. Derrida, however, and he is by no means alone in this, privileges the transformative potential of the temporal in a way that shifts critical attention from the immanent specificities of the present. The danger then is that dazzled and bewitched by the prospect of an indeterminate justiceto-come, we lose sight of law in its actuality - our vigilance with regard to the future threatens to blind us to the contemporary. If, as Derrida finally seems to believe, the spectral is of the future, then the transformation of the present is offered insofar as we accede to the perspective of the future. We would then see the present from the future, which, of course, is to treat the contemporary not as contemporary but as the past - the contemporary as it will have been. Such a perspective seems to suggest a disinclination to explore the possibility of a spatial redistribution of the contemporary. Not to engage more directly with the contemporary and its immanent possibilities may, therefore, come to be viewed, if one were to look into the future and speculate, as a massive and defining loss of nerve of at least one recent strand of contemporary critical thinking.

Evidence of this loss of nerve is perhaps indicated by the almost pathological investment in the theoretical affordances of the future anterior as the syntactical marker of this way of thinking, naming a break with the contemporary that risks rendering it not simply 'past' and 'over and done with', but effaced, insofar as it facilitates the imagined retrojection, from a time to come, of a new, different past that would be our contemporary. Derrida comments in Of Grammatology:

The future can only be anticipated in the form of an absolute danger. It is that which breaks absolutely with constituted normality and can only be proclaimed, presented, as a sort of monstrosity. For that future world and for that within it which will have put into question the values of sign, word, and writing, for that which guides our future anterior, there is yet no exergue. (1976: 5)

Simon Critchley comments that '[t]he temporality of the future anterior is something that Derrida has exploited throughout his work' and that it is important to him because 'it is a tense that escapes the time of the present' (Critchley 1992: 115). He goes on to say that it presents a temporality that is irreducible to what Derrida would call 'the metaphysics of presence' (115), suggesting that 'it is perhaps the time of ethics' (116). These peculiar affordances of the future anterior have made it attractive to other contemporary thinkers, though not always with the radical disengagement from the contemporary that the tense marks for Derrida. Jean-François Lyotard, for instance, argues that the future anterior is the tense of the postmodern: 'Post modern would have to be understood according to the paradox of the future (post) anterior (modo)' (1984: 81). This does not signal a rejection of the contemporary so much as a 
bracketing, from a position of resolute contemporaneity, of contemporary norms and conventions:

A postmodern artist or writer is in the position of a philosopher: the text he writes, the work he produces are not in principle governed by preestablished rules, and they cannot be judged according to a determining judgment, by applying familiar categories to the text or to the work. Those rules and categories are what the work of art itself is looking for. The artist and the writer, then, are working without rules in order to formulate the rules of what will have been done. (1984: 81)

The postmodernist, on this reading, invents the future by reinventing the contemporary. For Lyotard, then, the future anterior is primarily a marker of creation and experimentation. Manuel P. Arriaga is quite right when he says that '[f]or Lyotard, the notion of the postmodern is virtually identical with how philosophy in its authentic sense operates' (2006: 86). This is not unrelated to the temporality operative in Deleuze's thinking, other significant differences between the two philosophers' work notwithstanding. The most obvious connection is to Deleuze's notion of a third present, besides 'the measureless or dislocated present as the time of depth and subversion' and 'the variable and measured present as the time of actualization', one 'pertaining to the Aion' (1990: 168). More generally, Lyotardian temporality can be understood to accord with Deleuze and Guattari's claim in A Thousand Plateaus that "in order to give a positive meaning to the idea of a "presentiment" of what does not yet exist, it is necessary to demonstrate that what does not yet exist is already in action, in a different form than that of its existence' (2005: 431). Alain Badiou also deploys the logic of the future anterior in a way that remains deeply engaged with the contemporary. Jacques Lecercle has suggested that this can be traced back to Badiou's reading of Beckett, who 'helps Badiou to think the temporality of the event as in the future anterior' (2010: 142). Lecercle rightly sees this temporal logic at work in Badiou's ideas of event, subjectivity, and truth:

When the procedure of truth is initiated, the prospective subject of such truth must make a decision, the decision that what she is being faithful to will turn out to have been an event (you will have noted the appearance of the grammatical markers of a past in the future, or future anterior). (142)

Badiou himself names 'the future anterior as truth's own temporal regime or register' (1991: 26). For Derrida, however, precisely this imbrication of the future anterior in the present renders it suspect. In 'Force of Law: The "Mystical Foundation of Authority", for instance, he sees the future anterior as too easily recuperable as a justification for law-founding violence:

In these situations said to found law (droit) or state, the grammatical category of the future anterior all too well resembles a modification of the present to describe the violence in progress. It consists, precisely, in, feigning the presence or simple modalization of 
presence. Those who say 'our time', while thinking 'our present' in light of a future anterior present do not know very well, by definition, what they are saying. (1990: 991)

Even the 'retrospective anticipation' of 'being-towards-death' in the work of Heidegger remains unsatisfactorily tied to the present. In this regard Derrida speaks of 'the future anterior that precedes even the present, which it only seems to modify' (1993a: 55). For Derrida, then, as I have suggested, the attraction of the future anterior lies not in how it might modify the present, but rather in its potential to tend to a future completely disjoined from the contemporary as it is currently lived. Mark Currie has described Derrida's interest thus: 'Future anteriority more or less shows itself to be the same structure as the messianic without messianism: that is to say, an empty or contentless temporal structure that can nevertheless be characterised as an obligation' (2013: 94). This is the future anterior on the side of the impossible, rather than the possible. As Bennington puts it, '[t]his appeal to an irreducibly futural future (the interminably à venir or to-come) suspends deconstruction always this side of any ethical or political doctrine or programme' (2000: 16). But, as Antonio Calcagno points out, Derrida would increasingly come to see this " to come" as opposed to the grammatical name of the future anterior' precisely because the 'to come' marks a more radical break with the present (2007: 5):

This grammatical structure, for Derrida, demonstrates the tension of both past and future as exemplified in the metaphor of the promise; still, the structure is too much a modification of the present because the 'living present' is still the primary reference point. The future anterior is only anterior and future insofar as it refers to a present tense that claims to present things fully. This being the case, Derrida would be wary to adopt the grammatical structure of time as future anterior, for its sense is much too rooted in the foundational and regulative tense of the present. (5)

In Philosophy in a Time of Terror, Derrida suggests that the temporality of the event of trauma 'proceeds neither from the now that is present nor from the present that is past but from an im-presentable to come'. This, he suggests, marks 'a future so radically to come that it resists even the grammar of the future anterior' (Borradori 2003: 97). Once again, then, what preoccupies Derrida is the possibility of a radically disjunctive move from the contemporary, articulated from a position of projected retrospectivity, which would be the condition of the possibility of an alternative contemporary to come.

It is important to register, even just parenthetically, that this futural imperative, issued on ethical grounds, can be understood as colluding with other contemporary forces that direct attention away from the present and towards the future. Two related forces stand out prominently: the Liberal belief in progress which can be interpreted as masking both a kind of cultural cowardice and self-loathing, and capitalism's dependency upon a model of unsatisfied and, ultimately, insatiable desire. 
Twentieth-century literary critic Lionel Trilling casts the future-orientation of the former in sharp relief when he writes:

The past has been a weary failure, the present cannot matter, for it is but a step forward to the final judgement; we look to the future when the best of the works of man will seem but the futile and slightly disgusting twitching of primeval creatures: thus, in the name of a superior and contemptuous posterity, we express our self-hatred -and our desire for power. (1965: 22)

The ways in which capitalism manipulates notions of the future in order to stimulate consumer desire, animating market forces more generally, should not need any elaboration. Add to these two characteristics of our time the radical, ethical futureorientation of the strand of contemporary theory that I have been attempting to outline and what you have is an undoubtedly strange, disturbing, and complex nexus of complicity.

The ethico-futural imperative of Derridean ethics (and one could make similar arguments about Levinas, Blanchot, and so on) find what might be understood as an inverse parallel in the work of Theodor Adorno. Whereas in the former camp the emphasis is on being vigilant to an alterity that is always to come-and literature is put into service to this end and is offered as, simultaneously, the name, medium, and enactment of that vigilance - for Adorno the ethical stance necessitates the eternal bearing witness to the past singular catastrophe of the holocaust, an 'endless work of mourning', in other words (Rancière 2009: 130). And as with the spectral logic of Derrida, this work of witnessing is most urgent precisely where it seems to be least efficacious, again suggesting a debt to Hölderlin's belief that the saving power emerges at the point of greatest danger. For Adorno this necessitates a dissruptive and dissociative aesthetics: 'For the sake of reconciliation, authentic works must blot out every trace of reconciliation in memory' (Adorno 2002: 234). Both Derridean and Adornian ethics represent attitudes that look beyond the contemporary on the basis of a past or expected rupture that they feel compelled to witness or to anticipate. Literature, in serving this purpose, is reduced to an ethical witnessing of what is in essence the un(re)presentable. Such stances risk absolutising the heterogeneous in such a way as to enforce a kind of homogeneity - the gesture of a radical opening is, in effect, that is to say, a peremptory closing. This is what Rancière has identified as a kind of subjection to the law of the Other operative within the contemporary ethical turn (2009: 131). He writes:

The reign of ethics is not the reign of moral judgements over the operations of art or of political action. On the contrary, it signifies the constitution of an indistinct sphere in which not only is the specificity of political and artistic practices dissolved, but so also is that which formed the very core of 'old morality': the distinction between fact and law, between what is and what ought to be. Ethics amounts to the dissolution of norm into fact: in other words, the subsumption of all forms of discourse and practice beneath the same indistinct point of view. (2009: 109-10) 
The 'radicality of this law', he goes on, 'which leaves no alternative, equates to the simple constraint of an order of things' (110). This generalised consensual dissensus, commanded by the law of the Other, undermines the dissensual conditions necessary for politics, thus effecting a kind of evacuation or nullification of the political (115). It is precisely in this regard that Judith Butler comments that she has 'worried that the return to ethics has constituted an escape from politics' (2000: 15). And it is this fetishisation of radical alterity and of the procedures believed to safeguard it that inform and shape the reductive aesthetic outlook that I have described, an outlook that loses focus on the contemporary by putting art into the service of vigilant anticipation or of perpetual mourning. Rancière goes on: 'This tendency of differences in politics and right to disappear in the indistinctness of ethics is also defining of a certain present of the arts and of aesthetic reflection' (120). That present moment of the arts - if indeed it is still present - is motivated, as I have been suggesting, by the anticipation or memory of an unprecedented, strictly incalculable, rupture or event. We have already noted the similarities between such an occurrence and trauma in Derrida's discussion of a 'to come' that exceeds the logic of the future anterior in Philosophy in a Time of Terror. Rancière, too, draws the analogy with terror:

The unrepresentable, which is the central category of the ethical turn in aesthetic reflection, is also a category that produces an indistinction between right and fact, occupying the same place in aesthetic reflection that terror does on the political plane. (123)

It is on similar grounds that Badiou opposes an 'ethics in general', arguing instead for 'ethics of processes by which we treat the possibilities of a situation' (Badiou 2001: 16). 'Ethics does not exist' he writes, '[t]here is only the ethic-of (of politics, of love, of science, of art)' (28). For anything like a Levinasian ethics of alterity to be coherent, Badiou argues, it must be understood as religion rather than as philosophy:

[E]thics requires that the Other be in some sense carried by a principle of alterity which transcends mere finite experience. Levinas calls this principle the 'Altogether-Other', and it is quite obviously the ethical name for God. There can be no Other if he is not the immediate phenomenon of the Altogether-Other. There can be no finite devotion to the non-identical if it is not sustained by the infinite devotion of the principle to that which subsists outside it. There can be no ethics without God the ineffable. (22)

'What then becomes of this category if we claim to suppress, or mask, its religious character, all the while preserving the abstract arrangement of its apparent constitution ('recognition of the other', etc)?' Badiou's answer to his own question is scathing: 'The answer is obvious: a dog's dinner' (23). This sort of empty ethical turn is, he suggests, characteristic of the contemporary world's incapacity to 'name and strive for a Good' (30). But the tendency to will nothing at all slips all too easily into a will to nothingness. Badiou diagnoses the resulting attitude as a form of nihilism, which is perhaps not surprising given the Nietzschean definition of nihilism as a devaluing of values that 
negates the world. Badiou sees this negative will, this will to nothingness, as 'a kind of understudy of blind necessity' (30), constituting a contemporary subjectivity that accords with the consensual imperative demanded by 'the logic of Capital' (30). The consequence of the contemporary ethical turn, if it is followed, is, then, for Badiou, a 'debased' and 'apathetic' 'public consensus' (31). Ethics 'confirms, then, the absence of any project, of any emancipatory politics, or any genuinely collective cause' (31). 'The very idea of a consensual "ethics", Badiou goes on, 'is a powerful contributor to subjective resignation and acceptance of the status quo' (32).

How might we move beyond the consensus of the contemporary ethical turn? How might we, in other words, retreat from this absolutisation of heterogeneity that in fact works against heterogeneity, dispelling dissensus and commanding consensus? Rancière writes:

Breaking with today's ethical configuration, and returning the inventions of politics and art to their difference, entails rejecting the fantasy of their purity, giving back to these inventions their status as cuts that are always ambiguous, precarious, litigious. This necessarily entails divorcing them from every theology of time, from every thought of a primordial trauma or of a salvation to come. (2009: 132)

In other words, what is required is a move away from the sublime, impossible, unfigurable, absolute distance of the future, towards a proximity with the complex contemporary, a shift in focus away from temporal imminence, towards an engagement with spatial immanence, a move - ultimately for the sake of justice-away from justice and towards law, in full awareness that hands will not remain clean.

I would like to explore the possibility that this rethinking of the contemporary ethical turn gestures towards a more promising alternative way of responding to the question of art and politics, of literature and life. Indeed I would like to venture the hypothesis that the Derridean, Levinasian, and Adornian positions I have been outlining can be understood as characteristic of an identifiable tradition in philosophy and aesthetics and that it can be more clearly understood in contradistinction to a more recently emerging philosophical and aesthetic response to the question of art and politics, a response that in encouraging the cultivation of a proximity with the contemporary might perhaps allow us to contextualise more fully Rancière's suggestion that we ought to move away from an ontology of time. It is in the move away from theoretical futurophilia that I will suggest the impulse of countertextuality can be located.

Already on the basis of the names I have mentioned, it should be possible to discern a possible way of framing the former tradition. ${ }^{2}$ Derrida, Levinas, Blanchot form a fairly coherent grouping, one that invites the name Heidegger to be added to it. Adorno, more heavily invested in the past than the future, seems an unlikely companion here, though he too, I have argued, articulates an ethical position that devalues the contemporary in a way that threatens to neutralise dissensus. But then, recalling Hölderlin's name, a longer view can be taken, allowing a perspective that would see all 
of these thinkers as forming a part of a particular tradition in post-Kantian philosophy that has its orientation set early on by Kant's third Critique and the theoretical work of the early German romantics. Though this legacy is deserving of further consideration in this regard, I shall here simply highlight as important Kant's theory of the sublime which, as Adorno remarks in Aesthetic Theory, 'later became the historical constituent of art itself' (2002: 196), and the future-orientation of the Frühromantiker which was inspired, at least in part, by the 'practical' turn in Fichte's Wissenschaftslehre, which positions the absolute as something that one strives (and always fails) to achieve, rather than uncover through logical deduction. The theory of the sublime provides an influential structural model for the singular event that resists representation by bodying forth the principle of alterity. Early German romanticism can be understood as pioneering a sublime aesthetic apophasis in relation to the absolute, positioning poetry as having the potential to transfigure the world by gesturing beyond it, radically opening the world, in an irruptive procedure, to what is to come. As Friedrich Schlegel puts it in the famous Athenaeum Fragment 116, 'The romantic kind of poetry is still in the state of becoming; that, in fact, is its real essence: that it should forever be becoming and never be perfected' (1971: 175). Philippe Lacoue-Labarthe and Jean-Luc Nancy make amply clear in The Literary Absolute (1988) that the fragmentary imperative of early German romanticism was motivated by a desire to maintain an ongoing, irresolvable incompletion in written form, an incompletion resolutely open to what is to come. Blanchot, in the influential essay 'The Athenaeum', asserts that 'the future belongs in its entirety to romanticism because romanticism alone founds it' (2003: 356).

In light of this more historical framework, the tensions between Adorno and the French thinkers working within the post-Heideggerian tradition dissolve in a distant but binding familiarity, and another name immediately suggests itself, that of Walter Benjamin, whose first major work (his doctoral thesis) was titled 'The Concept of Criticism in Early German Romanticism' (1996), and whose theorisation of a 'weak messianicity' in his 'On the Concept of History' (2006) proved so influential on both the French and German theoretical traditions. In light of this genealogy (which I am only briefly indicating here) I would define the tradition I have been outlining - the tradition that orients itself, aesthetically and politically, to a pre- or post-contemporaneous event for the sake of rupturing the sameness of the present in order either to establish the conditions for radical transfiguration, or to bear witness, in an act of mourning, to the impossibility of radical transfiguration, in a way that is perceived to offer its own, perhaps minimal, ethical purchase-as romantic. It is in this sense that Lacoue-Labarthe and Nancy, both of whom I would add to this group, write that ' $[w]$ hat interests us in romanticism is that we still belong to the era it opened up' (1988: 15). And it is also in this regard that Badiou, whom I would not include in this group, writes: 'What is ultimately at stake here can be formulated in terms of the following question which weighs upon us and threatens to exhaust us: can we be delivered, finally delivered, from our subjection to Romanticism?' (2004: 22). This might help articulate the alternative ethico-aesthetic tradition that 
I am suggesting might be understood as marking a departure from what I will now call the legacy of romanticism. If the tradition reaching from Schlegel to Nancy is characterised by an absolute break with the contemporary, a moment of complete alterity figured either as justice, catastrophe, democracy, deconstruction, or literature, commanding from us a response of vigilance, messianic anticipation, or bearing witness, in a manner peculiarly assimilable to, variously, secular Judaism and the structural mechanisms of negative theology, then we might already, on the basis of the implicated binary alternatives, anticipate what this other, non- or post-romantic tradition might look like. We might expect it to be more closely aligned with spatiality, with the contemporary, with a political project that is simultaneously more engaged and more modest, that is prepared to deal with law, that is aligned with the present, and perhaps even with presence, favouring, perhaps, a kind of strategic countertextual phonocentrism.... Perhaps, perhaps.

Before looking at who might be included in this alternative tradition, it is important to pursue some of these themes to see if any of them might act as basic principles on the grounds of which the identity of this tradition might be constructed. The most obvious place to start - right here, right now, at this very moment - is with the right here and the right now. With the contemporary, that is to say. What might be meant by the contemporary? For Rancière the contemporary might perhaps best be understood as the current 'state of things', the current 'distribution of the sensible' (le partage du sensible) which can broadly, and quite simply, be understood as 'a set of relations between the perceptible, the thinkable and the doable that defines a common world, defining thereby the way in which and the extent to which this or that class of human beings takes part in that common world' (Rancière 2012: 11). The contemporary, this state of things, is 'a fiction': 'A fiction is not an imaginary tale. It is the construction of a set of relations between sense and sense, between things that are said to be perceptible and the sense that can be made of those things' (11). The time in which we live, therefore, is always a reference to a particular arrangement of the sensible, an arrangement that ultimately regulates our sense of what is possible and what is impossible. As Rancière points out, “'Times have changed' means: this is no longer possible' (12). The state of things, the contemporary, ought to be understood, therefore, as an 'interdiction' (12), as a 'medium of exclusion' (11), insofar as time - the time in which we live - is invoked as a 'principle of impossibility' (12). An interesting conclusion one can draw from this idea that the contemporary is the regulation of time as a principle of impossibility is that we, who are said to occupy the contemporary, are never adequately contemporaneous with it. We are not contemporary, not 'with' time, but rather subjected to it. The homogeneous time of the contemporary is, Rancière suggests, 'a time that makes those who live in it unable to master it, unable to understand what it makes possible or impossible, always walking too slowly or too fast to be contemporaneous with the intelligence of the process' (20). It is precisely the fact that the contemporary (and its manipulation) is the means 


\section{CounterText}

of regulating the distribution of the sensible which, according to Rancière, 'most of the discourses about "our time", including those that pretend to provide a radical critique of that time', neglect (23). He writes:

I would like to oppose to those analyses about the reign of the present an entirely different view: our time is not framed by the sole speed of the development of capital. It is framed by the institutions which make the coincidence and non-coincidence of times their own affair. (23)

We might venture to say that in collapsing temporality into a single ethico-temporal field of the 'to come' or the eternal past, the contemporary ethical turn in theory, and the aesthetic and political programme that it subsequently, even if implicitly, promotes, are complicit in this homogenisation. Rancière comments:

The forms of critical thinking that dominate today basically follow the dominant plot all the more easily, as the logic of domination has integrated the logic of its critique, asserting at once the homogeneity of a global process of historical evolution and the inner split that makes those who live in 'this' time understand the way they are carried along by the global process. (26)

The task, then, is to become properly contemporaneous with the contemporary - a situation that, from the perspective of the contemporary, could only be judged untimely (in the sense that Nietzsche used unzeitgemässe in Untimely Meditations, where, as Agamben puts it, he 'situates his own claim for "relevance", his "contemporariness" with respect to the present, in a disconnection and out-of-jointness' (Agamben 2011: 11). As Roland Barthes says rather pithily in a note in his lectures from the Collège de France: 'The contemporary is the untimely' (Agamben 2011: 10). And, as Agamben puts it in his essay 'What is the Contemporary?':

Those who are truly contemporary, who truly belong to their time, are those who neither perfectly coincide with it nor adjust themselves to its demands. They are thus in this sense irrelevant. But precisely because of this condition, precisely through this disconnection and this anachronism, they are more capable than others of perceiving and grasping their own time. (2011: 11)

To be contemporary would be to be adequate to the contemporary's own manipulation of the distribution of the sensible on the basis of time as the principle of impossibility, allowing the emergence of what we might call a counter-contemporary that emerges through and against the textual construction of the contemporary hegemony. It is important to distinguish this approximation of the contemporary from what Gianni Vattimo, in the book The Transparent Society, describes as a desire for 'the utopia of absolute self-transparency' engendered by a Jetztzeit, or contemporaneity, that, through technology, has reduced 'history to the level of simultaneity' (Vattimo 1989: 17). For Rancière, what I am positing as the counter-contemporary countertextuality 
would be 'the practice of dissensus, constructing another time in the time of domination, the time of equality within the time of inequality' (2012: 28). This simultaneous assertion of one time at the same time as another time, the positing, that is to say of another contemporary, establishes a heterogeneous simultaneity that produces the conditions in which the contemporary can be re-imagined, and in which the line between the possible and the impossible can be rethought and redrawn (by contrast, an ethics that simply brackets the contemporary and focuses on a moment of futural rupture - the ethics of the impossible, in fact - leaves the division of the possible and the impossible unquestioned). This procedure understands time-again, insofar as the time in which we live, the contemporary, is the name of a particular arrangement of the sensible - as primarily spatially immanent and, only secondarily, as temporally imminent. The production of heterotopias is linked, therefore, in a complex way to the production of heterochronies, insofar as heterochronies-'combinations of times that are normally incompatible' (34) - amount to a 'redistribution of times that invents new capacities of framing a present' (36).

What kind of imperative for art and literature might be derived from this? Clearly the aesthetics of futural ruptural break favoured by the romantic tradition are inadequate here. Casting ahead for a moment, one might imagine that this alternative, post-romantic tradition that I am attempting to sketch out would be more inclined to an aesthetic that is in some sense at least partly continuous with the contemporary everyday - able to engage with it and oppose it, encountering and countering, through subtle processual shifts and displacements. Whereas in the former regime the principle of alterity would be embodied in the ideal of the autonomy of the work of art, emblematic of an absolute distance, in the latter we might imagine a more modest heteronomy, characteristic of the artwork's proximity to the contemporary state of things. But Rancière is clear: "'pushed to the extreme”, each of these scenarios entails its own entropy, its own end of art' (2010: 132). As Agamben puts it,

Contemporariness is, then, a singular relationship with one's own time, which adheres to it and, at the same time, keeps a distance from it. More precisely, it is that relationship with time that adheres to it through a disjunction and an anachronism. Those who coincide too well with the epoch, those who are perfectly tied to it in every respect, are not contemporaries, precisely because they do not manage to see it; they are not able to firmly hold their gaze on it. (2011: 11)

Agamben imagines the poet as, at least ideally, an appropriate representative of the disjointed contemporary. He 'must firmly hold his gaze on his own time. But what does he who sees his time actually see?' (13). Agamben's answer is again suggestive of spatial immanence, rather than temporal imminence: 'The contemporary is he who firmly holds his gaze on his own time so as to perceive not its light but rather its darkness' (13). Not to see nothing (where darkness would merely be understood as 
'a privative notion', the 'simple absence of light' [13]), but to see 'the darkness of his time as something that concerns him, as something that never ceases to engage him' (14). Contemporariness is defined by a particular balancing of 'distancing and nearness' (17) and, perhaps unsurprisingly, 'contemporaries are rare' (14), since most people, fixated on the light of the contemporary, are too near and, thus, too remote.

Agamben writes with a poetic flourish that is, in itself, compelling; but how might we contextualise further this darkness of the present? Well, there are parallels with the notion of the actual that Foucault develops in The Archaeology of Knowledge. There he articulates the difficulty of describing adequately what he calls 'the archive of a society, a culture, or a civilisation' (Foucault 2002: 146). It is a task that seems to call for both 'chronological distance' and being 'as close as possible' (147). He seems to suggest, however, that there is a critical distance where the two requirements are balanced appropriately. He writes:

The analysis of the archive, then, involves a privileged region [the actual in question]: at once close to us, and different from our present existence [notre actualité], it is the border of time that surrounds our presence, which overhangs it, and which indicates it in its otherness; it is that which, outside ourselves, delimits us. (147)

This border-space actuality is important, '[n]ot because it would enable us to draw up a table of our distinctive features, and to sketch out in advance the face that we will have in the future' (147). Rather, it is important because it challenges the homogeneity of the contemporary. Foucault continues:

[I]t deprives us of our continuities; it dissipates that temporal identity in which we are pleased to look at ourselves when we wish to exorcise the discontinuities of history; it breaks the thread of transcendental teleologies; and where anthropological thought once questioned man's being or subjectivity, it now bursts open the other, and the outside. (147)

We might almost think of Foucault's notion of the actual (which, as l'actuel in French, usually refers to that which is current or present) as being closer to what we might think of as inactual, and it is worth recalling that l'inactuel, in French, means the untimely.

Deleuze and Guattari, who in What is Philosophy? complain that 'We lack resistance to the present' (2009: 108), emphasise the importance of Foucault's discussion of the actual. They write:

Acting counter to the past, and therefore on the present, for the benefit, let us hope, of a future - but the future is not a historical future, not even a utopian history, it is the infinite Now, the Nun that Plato already distinguished from every present: the Intensive or Untimely, not an instant but a becoming. Again, is this not what Foucault called the Actual? But how could the concept now be called the actual when Nietzsche called it the inactual? Because, for Foucault, what matters is the difference between the present and 
the actual. The actual is not what we are but, rather, what we become, what we are in the process of becoming - that is to say, the Other, our becoming-other. The present, on the contrary, is what we are and, thereby, what already we are ceasing to be. [...] It is not that the actual is the utopian prefiguration of a future that is still part of our history. Rather, it is the now of our becoming. (2009: 112)

It is clear therefore that Deleuze equates his own idea of becoming with both Nietzsche's untimely and Foucault's actual. Locating these subversive foci, seeing the darkness beyond the light of the contemporary, as Agamben has it, is, for Deleuze, as we might now expect, a task of a sort of immanent constructivism, by which alternative immanent contemporaries are articulated. Deleuze writes: 'The diagnosis of becomings in every passing present is what Nietzsche assigned to the philosopher as physician, "physician of civilisation", or inventor of new immanent modes of existence' (Deleuze and Guattari 2009: 113). This notion of time that is located as spatially immanent has been a recurring theme, and here in the Deleuzian context it ought to be understood as a 'stratigraphic time' (2009: 58), by which he means to indicate a 'co-existence of plans, not succession of systems' (2009: 59). Slavoj Žižek, in Organs Without Bodies, remarks on the irony of this, saying:

The paradox is thus that transcendental becoming inscribes itself into the order of positive being, of constituted reality, in the guise of its very opposite, of a static superimposition, of a crystallised freeze of historical development. This Deleuzian eternity is, of course, not simply outside time; rather, in the 'stratigraphic' superimposition, in this moment of stasis, it is time itself which we experience, time as opposed to the evolutionary flow of things within time. (2009: 9-10)

John Rajchman is surely right when he argues that, for Deleuze, 'contemporary moments in thought arise in "deterritorialising" conditions and sites, often cities (rather than states), which make possible new ideas, while casting older ones, by way of juxtaposition, in a new light, giving them a fresh actualité, a new contemporaneity' (Rajchman: 129). (It is worth noting-though I won't pursue it here-that the terminology regarding the actual is further complicated if you take into account the crucial Deleuzean distinction between the virtual and the actual. Foucault's notion of the actual would in fact equate with the 'virtual' in this context.)

I suggest that this marks the outline of an emergent post-romantic response to contemporary questions of aesthetics, politics, and literature. What seems to emerge as critical for this group of thinkers is that art ought to engage directly with the contemporary and with the conditions of its production, and ought to have the potential to suspend and reconstruct social relations. The question that remains is whether literature today and contemporary (post-)literary culture are able to offer such an engagement, and whether our conception of the literary needs to be reconfigured and expanded to include media, manifestations, and performances not typically thought of as literary. That, perhaps, is the question of the countertextual. 


\section{CounterText}

I will conclude with a cue from D. H. Lawrence who, in 1936, wrote a preface to the American edition of his New Poems in which, contra poetry enchanted by the future and poetry enchanted by the past, he endorses 'the poetry of that which is at hand: the immediate present' (287). Whereas he sees the poetry of the future and of the past as tending towards an 'exquisite finality', in the poetry of the immediate present 'there is no perfection, no consummation, nothing finished' (287). 'Give me nothing fixed, set, static', he writes (288), '[t]ell me of the mystery of the inexhaustible, foreverunfolding creative spark' (287). Such poetry is, he admits, 'rare' (291). Certainly, our literature of the present will be something entirely different from that of Lawrence's age. It may be rare, or there may be a good deal of it. And that is perhaps the principal provocation of CounterText: the literature (or the literary) of the contemporary isn't to come, it is likely (necessarily) already here, and the challenge is to recognise it as such. If, as Blanchot believed, literature ought to be a question, where, we ask in the spirit of the countertextual, is that question being articulated now?

\section{Notes}

1. An early version of this paper was presented to the Futures of Literature Network in Malta on 14 June 2013 and I'm grateful for the feedback I received there. I'm particularly indebted to Ivan Callus and Giuliana Fenech for many thought-provoking and enlightening discussions on the issues raised in this paper. I'd also like to thank Kurt Borg for his insightful comments.

2. Agamben sets out a similar delineation of two traditions, one affiliated to transcendence, the other to immanence (1999: 239). Benjamin Noys uses this as his starting point in The Persistence of the Negative: A Critique of Contemporary Continental Theory (2012).

\section{References}

Adorno, Theodor (1984), Aesthetic Theory, trans. Robert Hullot-Kentor, London and New York: Continuum.

Agamben, Giorgio (1999), Potentialities, trans. Daniel Heller-Roazen, Stanford: Stanford University Press. Agamben, Giorgio (2011), 'What is the Contemporary?', in Nudities, trans. David Kishik and Stefan Pedatella, Stanford: Stanford University Press.

Arriaga, Manuel P. (2006), The Modernist-Postmodernist Quarrel on Philosophy and Justice: A Possible Levinasian Mediation, Oxford: Lexington Books.

Badiou, Alain (1991), 'On a Finally Objectless Subject', in Who Comes After the Subject?, ed. Eduardo Cadava, Peter Connor, and Jean-Luc Nancy, New York and London: Routledge.

Badiou, Alain (2001), Ethics: An Essay on the Understanding of Evil, trans. Peter Hallward, London and New York: Verso.

Badiou, Alain (2004), Theoretical Writings, trans. Ray brassier and Alberto Toscano, London and New York: Continuum.

Benjamin, Walter (1996), 'The Concept of Criticism in German Romanticism', in Selected Writings: Volume 1, 1913-1926, trans. David Lachterman et al., ed. Marcus Bullock and Michael W. Jennings, Cambridge MA and London: The Belknap Press of Harvard University Press.

Benjamin, Walter (2006), 'On the Concept of History', in Walter Benjamin: Selected Writings, Vol. 4: 1938-1940, trans Edmund Jephcott et al., Cambridge, MA and London: Harvard University Press.

Bennington, Geoffrey (1994), 'Towards a Criticism of the Future', in Legislations: The Politics of Deconstruction, London: Verso. 
Bennington, Geoffrey (2000), Interrupting Derrida, London and New York: Routledge.

Bennington, Geoffrey (2001), 'Is it Time?', in The Moment, ed. Heidrun Friese, Liverpool: Liverpool University Press.

Blanchot, Maurice (2003), Infinite Conversation, trans. Susan Hanson, Minneapolis and London: University of Minnesota Press.

Borradori, Giovanna (2003), Philosophy in a Time of Terror: Dialogues with Jürgen Habermas and Jacques Derrida, Chicago and London: The University of Chicago Press.

Butler, Judith (2000), 'Ethical Ambivalence', in The Turn to Ethics, ed. Marjorie Garber, Beatrice Hanssen and Rebecca L. Walkowitz, New York and London: Routledge.

Calcagno, Antonio (2007), Badiou and Derrida: Politics, Events and their Time, London and New York: Continuum.

Callus, Ivan and James Corby (2015), 'Editorial: Countertextuality and the Political', CounterText 1:1, v-x. Critchley, Simon (1992), The Ethics of Deconstruction: Derrida and Levinas, Oxford and Cambridge MA: Blackwell.

Currie, Mark (2013), The Unexpected: Narrative Temporality and the Philosophy of Surprise, Edinburgh: Edinburgh University Press.

Deleuze, Gilles (1990), The Logic of Sense, trans. Mark Lester, New York: Columbia University Press.

Deleuze, Gilles and Félix Guattari (2005), A Thousand Plateaus: Capitalism and Schizophrenia, trans. Brian Massumi, Minneapolis and London: University of Minnesota Press.

Deleuze, Gilles and Félix Guattari (2009), What is Philosophy?, trans. Hugh Tomlinson and Graham Burchill, London and New York: Verso.

Derrida, Jacques (1976), Of Grammatology, trans. Gayatri Chakravorty Spivak, Baltimore: Johns Hopkins University Press.

Derrida, Jacques (1990), 'Force of Law: The "Mystical Foundations of Authority"', trans. Mary Quaintance, Cardozo Law Review, 11:5-6, 919-1045.

Derrida, Jacques (1993a), Aporias, trans. Thomas Dutoit, Stanford California, Stanford University Press.

Derrida, Jacques (1993b), Plato's Pharmacy, in Disseminations, trans. Barbara Johnson, London: The Athlone Press.

Derrida, Jacques (1994), Spectres of Marx, trans. Peggy Kamuf, New York: Routledge.

Derrida, Jacques (1995), On the Name, trans. David Wood et al., Stanford: Stanford University Press.

Foucault, Michel (2002), Archaeology of Knowledge, trans. A.M. Sheridan Smith, London and New York: Routledge.

Heidegger, Martin (1977), The Question Concerning Technology and Other Essays, trans. William Lovitt, New York: Harper \& Row.

Hölderlin, Friedrich (2004), Poems and Fragments, trans. Michael Hamburger, London: Anvil Press Poetry. Kronick, Joseph G. (1999), Derrida and the Future of Literature, Albany: State University of New York Press. Lacoue-Labarthe, Philippe and Jean-Luc Nancy (1988), The Literary Absolute: The Theory of Literature in German Romanticism, trans. Philip Barnard and Cheryl Lester, Albany: State University of New York Press.

Lawrence, D.H. (1960), 'Preface to the American Edition of New Poems', in Selected Essays, London: Penguin.

Lecercle, Jean-Jacques (2010), Badiou and Deleuze Read Literature, Edinburgh: Edinburgh University Press.

Lyotard, Jean-François (1984), The Postmodern Condition: A Report on Knowledge, trans. Geoffrey Bennington and Brian Massumi, Manchester: Manchester University Press.

Lyotard, Jean-François (1993), 'Note on the Meaning of "Post-”', in Postmodernism: A Reader, ed. Thomas Docherty, New York: Columbia University Press.

Noys, Benjamin (2012), The Persistence of the Negative: A Critique of Contemporary Continental Theory, Edinburgh: Edinburgh University Press. 


\section{CounterText}

Rabinow, Paul (2008), Marking Time: On the Anthropology of the Contemporary, Princeton: Princeton University Press.

Rajchman, John (2011), 'The Contemporary: A New Idea?', in Aesthetics and Contemporary Art, Berlin: Sternberg Press.

Rancière, Jacques (2009), Aesthetics and its Discontents, trans. Steven Corcoran, Cambridge: Polity.

Rancière, Jacques (2010), Dissensus: On Politics and Aesthetics, trans. Steven Corcoran, London and New York: Continuum.

Rancière, Jacques (2012), 'In What Time Do We Live?', in The State of Things, ed. Marta Kuzma, Pablo Lafuente, Peter Osborne, London: Koenig Books.

Schlegel, Friedrich (1971), Friedrich Schlegel's Lucinde and the Fragments, trans. Peter Firchow, Minneapolis: University of Minnesota Press.

Trilling, Lionel (1965), E.M. Forster, New York: New Directions.

Vattimo, Gianni (1989), The Transparent Society, trans. David Webb, Cambridge: Polity. 